This is the accepted manuscript of the article, which has been published in Work, Employment and Society. 2019, 33(5), 777-793.

https://doi.org/10.1177/0950017019835133

\title{
Becoming a 'labour migrant': Immigration regulations as a frame of reference for migrant employment
}

\author{
Jukka Könönen \\ Tampere University, Finland
}

\begin{abstract}
This article addresses the role of immigration regulations as a frame of reference for migrant employment before obtaining permanent residency status. Drawing on interviews with non-EU migrants and service sector employers in the Helsinki area, the article examines how immigration regulations inform migrant employment and contribute to the hierarchisation of labour markets. The analysis focuses on the legal significance of employment for migrants during the immigration process, which is related to the financial requirements for residence permits and manifested in the work permit process in particular. Immigration regulations increase migrants' dependency on paid employment, consequently decreasing their bargaining power in the labour market. The findings demonstrate the changing dynamics of the supply and demand of labour in the low-paid service sector, where employers prefer to recruit migrants in temporary legal positions over local workers and 'labour migrants', resulting in what the author calls the juridical division of labour.
\end{abstract}

\section{Keywords}

division of labour; flexible work; immigration controls; labour markets; legal status; migrant labour; regularisation; residence permit

Corresponding author: Jukka Könönen. Institute for Advanced Social Research, FI33014 Tampere University, Finland. email: jukka.kononen@gmail.com 


\section{Introduction}

Migrant workers continue to play a significant role as flexible and precarious labour in low-paid labour markets in Western countries irrespective of their individual qualifications. According to Alberti (2015: 868), 'only limited research exists on the subjective reasons that lead these workers to take on precarious jobs in relation to their migratory paths'. In migration research, migrant workers have been regarded as a distinct category of labour due to their different valuation of employment opportunities. According to the famous argument presented by Piore (1979: 54), migrants have a purely instrumental relation to work due to their intention to invest the income accumulated in Western countries back in their home community. Similarly, Waldinger and Lichter (2003: 152) suggest that 'immigrants as workers are distinctively characterised by a dual frame of reference, in which conditions in the host society are always assessed relative to conditions in the home society'. The concept of 'dual frame of reference' persists in migration research as an explanation for migrants' willingness to take on low-paid and stigmatised work (e.g. Berntsen, 2016; Friberg and Midtbøen, 2018; McCollum and Findlay, 2015; Wills et al., 2010). However, this conception risks essentialising migrants' acceptance of precarious working conditions by disregarding the structural effects of immigration regulations on migrant employment. Migrants' willingness to take on precarious jobs cannot be distinguished from immigration policies, which increasingly compound migrants' residency status and rights with employment and produce juridically distinct categories of labour.

This article presents the argument that it is not migrants' home societies that form a 'dual frame of reference' for migrant employment, but rather immigration regulations, which stipulate various income requirements as a general precondition for 
residence permits issued on grounds other than humanitarian reasons. Several scholars have highlighted the connection between migrants' conditional legal statuses and their vulnerability in the labour market (e.g. de Genova 2002; Goldring and Landolt, 2013) and the hierarchising effects of immigration regulations for migrants' labour market positions (e.g. Anderson, 2010; Könönen, 2018). However, the empirical research often focuses on migrants' precarious and flexible working conditions - be they irregular migrants (e.g. Ahmad, 2008; Calavita, 2003), rejected asylum-seekers (Lewis et al., 2014) or EU citizens (e.g. Berntsen, 2016; Collum and Findlay, 2015) - without addressing in detail the migrants' legal situation and their consequent negotiations with the immigration system. Before migrants obtain permanent residency status, employment can have the strategic function of regularising their residency (e.g. Robertson 2011), as work may be necessary for fulfilling the income requirements for residence permits or family reunification. Indeed, working migrants can become what Piore (1979: 79-80) calls 'target earners', although here in relation to immigration regulations. Therefore, to understand migrants' position in the labour market, it is necessary to examine the different legal meanings of employment for migrants during the immigration process.

This article aims to conceptualise the hierarchising effects of immigration policies in the labour market by examining how immigration regulations inform migrant employment and how juridical hierarchies between different categories of labour affect the dynamics of labour markets. Empirically, the article is based on interviews conducted in Helsinki with service sector employers and working migrants who arrived as asylum seekers or students in Finland. These two migrant groups provide an interesting platform to examine immigration regulations as a frame of reference for migrant employment because of their conditional legal position and the function of 
work as a means for obtaining a more secure legal status. The analysis focuses on the legal significance of employment for migrants during the immigration process, which are related to income requirements for residence permits and manifested in the application process for a work permit in particular. The article also demonstrates the contradictory outcomes of immigration policies: non-recognised forms of migrant workers constitute an important flexible labour force in the low-paid labour market in the Helsinki area, yet strict work permit policies complicate their regularisation processes. This article contributes to the discussion on migrant workers as flexible labour by highlighting the role of immigration policies in constructing different juridical configurations of migrant labour and by rethinking the concepts of dual frame of reference and division of labour.

\section{Multiplication of migrant labour and the juridical division of labour}

Immigration policies - and for that matter, most migration research - operate on the basis of a strict separation of labour migration from humanitarian, student and family migration, even if economic motives pertain to migratory movements regardless of the assigned entry category. Despite the sustained demand for migrant labour in Western countries, low-skilled labour migration remains strictly regulated. Besides being a highly politicised issue (Anderson and Ruhs, 2010; Castles, 2011; Dauvergne and Marsden, 2014), the transformation of production and the proliferation of flexible employment arrangements since the Fordist period (Boltanski and Chiapello, 2005; Standing 2011) complicates the organisation of labour migration. State-regulated labour migration schemes resemble the Fordist planning economy model insofar as they presuppose that migrant workers are recruited from abroad well in advance for full-time employment in sectors defined as facing labour shortages. Several scholars have suggested that irregular migration provides flexible workers for post-Fordist capitalism, 
highlighting the hidden productivity of immigration law in creating deportable labour (Calavita, 2005; De Genova, 2002; Karakayali and Rigo, 2010). Migrants initially admitted for humanitarian, study or family reasons constitute an additional labour supply, often disregarded in debates on labour migration, which Pastore (2014) regards as a 'functional equivalent' to labour migration. However, labour market mobility, residence time and access to the welfare system vary among working migrants depending on their legal status. Thus, immigration regulations establish juridically disparate forms of migrant labour, with implications for the division of labour.

Immigration policies are always labour market policies because immigration controls not only regulate the number of potential workers but also directly affect the positions where migrants work. Migration management increasingly takes place inside the state, where the differentiation of legal statuses allows states to control migrants' 'freedom once they are within nationalized labour markets' (Sharma, 2006: 25). In Europe, EU citizens are exempt from the entry and labour market regulations to which third country nationals are subjected to various degrees depending on their entry category. In the case of 'labour migrants', immigration policies differentiate between forms of labour based on the duration of work (permanent or temporary/seasonal), required education (low-skilled or high-skilled work), or even the level of salary. Instead of simply 'labour migrants' or 'migrant labour', the proliferation of legal statuses for non-citizens leads to a variety of juridical configurations of migrant workers, resulting in what Mezzadra and Neilson (2013) call the multiplication of labour. In other words, alongside undocumented workers and various labour migrants, there are marriage-migrant-workers, student-migrant-workers, asylum seeker-workers and so on, each occupying a particular legal position in the labour market. The multiplication of migrant labour indicates different degrees of flexibility among 
working migrants due to differences in their legal entitlements and labour market mobility; in fact, it is usually precisely 'labour migrants' who are restricted to work in certain sectors (see Rosewarne, 2010).

Immigration policies legalise migrants in various ways, at the same time conferring different legal meanings on migrant employment. While irregular migrants are widely regarded as the paradigmatic form of precarious labour (Calavita, 2005; De Genova, 2002; Karakayali and Rigo, 2010), the possession of a legal status as such does not necessarily entitle migrants to welfare services nor guarantee the right to residency. The requirement of economic self-sufficiency for residency, as well as specific income requirements for residence permits and family reunification, increases migrants' dependence on paid employment. Additionally, migrants' access to welfare benefits is increasingly contingent on employment even in residence-based welfare systems, with the exception of humanitarian migrants (Könönen 2018). Rather than being external for migrant employment, immigration regulations intervene in the terms of the agreements between transacting parties in the labour market. As Anderson (2010: 301) writes, 'through the creation of categories of entrant, the imposition of employment relations and the construction of institutionalised uncertainty, immigration controls work to form types of labour with particular relations to employers and to labour markets.' Therefore, it is immigration law, rather than labour law (Freeland and Costello, 2015), that produces divisions and hierarchies in the labour market.

Migrants' conditional legal statuses alter their bargaining position in the labour market, consequently transforming the distribution of supply and demand among juridically different forms of labour. Several studies have demonstrated employers' preference for hiring migrants over the local population, highlighting the role of migrant workers as flexible labour in Western countries (Wills et al., 2010; Sassen, 2001; 
Anderson and Ruhs, 2010). In the context of the welfare state, the supply and demand of labour is differentiated between endogenous labour protected by the social security system, and exogenous labour, whose income is dependent on wages (see Moulier Boutang, 2002). In other words, the social security system forms a frame of reference in the labour market for those entitled to unemployment benefits, while the right to residency and access to other social rights can be at stake in employment for migrant workers. In addition to deportability (de Genova, 2002), migrant workers' flexibility emerges through dependence on paid employment, which limits their bargaining power and ability to move away from insecure employment (cf. Alberti, 2015). Immigration controls produce externalities in the labour market by exacerbating the vulnerability of migrant workers in that their residency and other rights are increasingly contingent on employment. Therefore, immigration policies are inherently workfare policies and work against the function of the welfare state in decommodification of labour (EspingAndersen, 1990).

The multiplication of migrant labour contributes to the changing dynamics of the labour market, which this article suggests can be conceptualised as the juridical division of labour. Wills and her colleagues (2010) use the concept of 'the migrant division of labour' to capture the importance of the foreign-born labour supply in low-paid labour markets, emphasising the roles played in this development by employer demand, migrants' dual frame of reference, state regulation and local entitlement to welfare benefits (see also McDowell, Batnitzky and Dyer, 2009). However, the multiplication of labour indicates a division inside 'the migrant division of labour', because the foreignborn population, as well as the categories of ethnicity and race, encompasses a variety of juridically different forms of labour, from permanent long-term residents to various categories of temporary migrants. While class, race and gender can affect the mobility 
and value of labour (e.g. Skeggs 2004) and discriminatory practices restrict migrants' employment opportunities, non-citizenship constitutes a structural level of discrimination (see Bosniak 2006). Ethnicity and race may be insufficient as explanatory factors in the hierarchisation of labour markets, because migrants from the Global South are increasingly subject to immigration regulations and consequently often work for years in disadvantaged legal positions. According to Goldring and Landolt (2011), precarious legal statuses have a long-term negative impact on the position of migrant workers in the labour market. Therefore, it is important to examine how immigration regulations inform migrant employment and how the proliferation of legal statuses contributes to the transformation of labour markets.

\section{The research and the context}

Finland has received a moderate number of migrants: in 2016, in addition to 5,651 asylum applicants, 19,148 third country nationals received residence permits for the purposes of study, work or family life. A total of 3,182 new work permits were issued for low-paid work, mainly in the restaurant, cleaning and gardening sectors. (Immigration Office 2017.) The annual number of immigrants has not changed considerably during the last ten years, except for the arrival of more than 32,000 asylum seekers in 2015 and a small reduction in student permits after the introduction of tuition fees for non-EU students in $2016 .{ }^{1}$ While effective removal policies have limited the extent of irregular migration in Finland, migrants in temporary positions are entitled to work legally, with certain restrictions, regardless of the entry category. In fact, asylum seekers, students and family migrants outnumber labour migrants in Finland despite the official aim to facilitate labour migration. In contrast to family migrants, students and asylum seekers have only limited social rights and face an insecure future concerning 
permanent residency. Asylum seekers are entitled to minimum income support and free accommodation in reception centres during the asylum process. They can also work without restrictions after three or six months, depending on the possession of valid travel documents on arrival. The only restriction on labour market access for non-EU students is the limit of 25 hours of work per week during the semester, excluding internships or work related to their studies. the issuance of a student permit requires proof of economic self-sufficiency, currently $€ 6,720$ per year, and private health insurance, as international students are not entitled to welfare services. In Finland, migrants can apply for residence permits on new grounds after arrival regardless of the initial entry category.

The research presented here focused not on particular ethnic groups, but rather on conditional legal statuses and the role of employment for migrants before they obtain permanent residency status. The analysis is based on 32 semi-structured in-depth interviews with non-EU migrants from Africa and $\mathrm{Asia}^{2}$ who had arrived in Finland mainly as students and asylum seekers and had worked in the low-paid labour market in the Helsinki area. At the time of the interviews, the majority of participants had been in Finland for between two and four years, and many of them had obtained or applied for a residence permit on other grounds. Interviews were conducted by the author in Helsinki, primarily in 2010. Of the interviewed migrants, 26 were men and 6 were women, and most were between 25 and 35 years of age. Interviews lasted approximately 90 minutes and were transcribed for analysis. The themes discussed in the interviews included the interviewees' migration history, the process of obtaining a residence permit and experiences in the labour market. To understand the role of non-EU workers in the lowpaid service sector in Finland, interviews with seven representatives of mid-sized companies operating in the cleaning and restaurant sectors in the Helsinki area were 
carried out in $2009 .{ }^{3}$ In addition to these interviews, the analysis is informed by the author's experience in migration solidarity activism in Finland over the last ten years. The author's first-hand experience assisting migrants in applying for residence permits provided information about the immigration bureaucracy and migrants' legal struggles that supports the analysis of the interview data and shows the continuing relevance of the problems addressed in interviews.

The present article focuses on the situation in the labour market in the Helsinki area, the main economic centre of Finland with a population of around 1.2 million, where the majority of the nation's foreign population and migrant communities are concentrated. The interview data is not representative of the situation of all migrant workers in Finland, but it provides information on the legal significance of employment for migrants and the hierarchising outcomes of immigration policies in the labour market. The legal framework regulating migrant employment has remained essentially the same since the interviews were conducted. The main legal change relevant for the legalisation process is the requirement that residence permit applications be submitted in person, effective since 2012; previously, employers could apply on behalf of workers. Additionally, the passport requirement for residence permit applications, introduced in 2016, can complicate the legalisation process of asylum seekers in particular. The increased number of asylum seekers and the introduction of university tuition fees will increase the number of migrants in need of paid employment, making the issues addressed in this article even more relevant. The following sections, based on the analysis of the interview data, address the flexible and mobile working conditions in the cleaning and restaurant sectors, the problems faced in applying for a work permit and the new division of labour in the low-paid service sector. 


\section{Mobile and flexible work in the low-paid service sector}

The migrants who were interviewed had entered the labour market via various trajectories, some having moved to the Helsinki area from reception centres in other regions of Finland or having combined temporary work in Helsinki with studies elsewhere. Despite different personal and legal situations, dependency on paid employment was a common feature highlighted in the interviews. For student interviewees, employment was a self-evident means to finance living expenses during their studies as well as to accumulate the funds needed to meet the income requirement for renewal of the residence permit. Asylum seeker interviewees preferred to live in Helsinki because of the employment and social opportunities available there. For them, work was initially a source of additional income as well as a necessity to cover the high cost of living in Helsinki, even when sharing an apartment with several people.

However, the main problem for interviewees was not so much getting a job as it was finding regular work. The interviewees had diverse work histories in Finland and were often initially employed as agency workers. One student from Africa described her experiences in the labour market as follows:

It was different every day, maybe you get some work or not. It depends - they can give you a four-hour shift, or a two-hour shift, whatever they need. If you got a shift, you go, but you don't know whether tomorrow you get anything. [...] Sometimes there are longer assignments, like for three weeks, so then I get the keys to the place, and I can do the cleaning in the evenings.

Regardless of entry category and occupational history, the interviewed migrants had worked mainly as cleaners and restaurant dishwashers in Helsinki. According to both the migrants and the employers who were interviewed, English had become the working 
language in the low-paid service sector, indicating the significant role of migrant workers. In Finland, the outsourcing of cleaning services to private companies since the 1990s has contributed to the disappearance of a fixed work place and work-related sociability (see also Ollus, 2016). Intensification of production takes place through the reorganisation of employment relations and the work process (see Boltanski and Chiapello, 2005). Part-time and short-term employment relations are widespread in the low-paid service sector: so-called zero-hour contracts, which define the working week as being anything from zero to forty hours with no guaranteed hours, are the paradigmatic form of precarious employment. In addition, work is dispersed across the whole city, often requiring movement between worksites during the day. The following quote from a South Asian asylum seeker illustrates how the only certainty in the service sector appeared to be constant insecurity:

They give shifts sometimes the same day, in the morning with two hours' notice, sometimes one week before. [...] They call me or send a message when you have that place and when you have this place. They can send me to do dishes only five or four hours before. So I must travel a lot to new places, I have to look where they are and travel. But I don't like to go every time to new places, it's not easy. That's why I look for a new job - I want to work in one place.

The main characteristics of migrant work as described in interviews were flexible employment arrangements and the consequent uncertainty of work schedules, resembling the situation reported in other Western countries (Abbasian and Hellgren, 2012; Aguiar and Herod, 2006; Wills et al., 2010). Flexible schedules can be suitable for students because being restricted to 25 hours of work per week prevents full-time employment during the semester, although the regulation is not systematically enforced. Similarly, asylum seekers can react to employment opportunities at short notice. 
Although their personal circumstances and the resources they had available affected the necessity to work, the uncertainty of work and insufficient income were common causes of stress for interviewees. Consequently, the fear of losing necessary income limited their opportunities to resist flexible employment arrangements. Employer interviewees, for their part, highlighted the flexibility of migrant workers and their willingness to move around the city and take any shifts available. As one of them explained,
A: The good thing in those foreign workers is the flexibility, that they are ready to go anywhere.
Q: Anytime?
A: Anytime, in principle. And there is always a reserve.
Q: Is there a difference compared to Finnish workers?

A: Yes. If I call you [a Finn] that 'you go now', you will say 'no, no'... We are used to different.

Mobility and flexibility emerged as important resources and requirements in the lowpaid labour market, where unpredictable schedules and changing work locations had transformed the coordinates of working hours and workplace, negatively affecting the supply of local workers. The interviewed migrants had mainly worked for established companies and complied with employment and immigration regulations. However, the flexibilisation of production has blurred the boundaries between legal and illegal work and between employee and self-employed (see Ruhs and Anderson, 2010; Sassen, 2001). Short-term work arrangements outsource risks to employees and transform workers into neoliberal subjects (see Foucault, 2008) responsible for negotiating adequate working hours. Scattered work sites can significantly complicate everyday life despite the limited number of hours actually worked, as happened to one African student who applied for a work permit because of the difficulty of combining studies 
with unpredictable work schedules:

It was a very unreliable job because you get a shift one day, but then you don’t get a shift. And then the problem is, if you don't get a shift, you don't go to school because you wait for the work. [...] It was really hard, because there are things waiting for you, but you don't know what happens tomorrow.

Part-time and flexible employment can provide the financial resources to pursue personal aspirations, but before long, acquiring the right to residency becomes the primary concern for migrants. To understand migrants' willingness to accept flexible and precarious employment relations, it is important to take into account immigration regulations, which increase their dependency on paid employment. For students, the income requirement for the renewal of the residence permit transforms the meaning of employment: even if they are able to support themselves, the failure to demonstrate at least $€ 6,000$ in available funds each year would endanger their residency. While the income requirements do not apply to asylum seekers, in their case, too, work had a strategic function in negotiating a more secure legal position. Immigration regulations inform migrant employment during the immigration process by conferring particular legal meanings on employment, which in the interview data was manifested in the application process for a work permit in particular.

\section{Becoming a labour migrant}

Work has a particular significance for migrants without permanent status in that it can enable them to apply for a residence permit. Like undocumented migrants (e.g. Coutin, 2003), migrants with temporary legal status also need to devise legalising strategies in order to stay in the country. Status mobility (Schuster, 2005) emerges as a necessity for non-EU graduates, who receive only a one-year extension (previously six months) to 
their residence permit in order to look for full-time work in Finland. For asylum seekers, employment can become a substitute for international protection in the prospect of a negative decision and removal order. The asylum process, including appeals, can take years to complete, which offers asylum seekers 'borrowed time' to consider alternatives (see Ahmad, 2008). The interviewed migrants were aware of alternative legalising paths, as an African interviewee who had first applied for asylum and later obtained a work permit explained:

You have to look for other options. You have to help yourself, maybe look for a woman, to get a job, maybe cleaning. [...] I had to think of those options, what will I do if there will be a favourable situation. Because it's not good if the police deport me back home, and I have to suffer.

For interviewees, employment was the primary strategy to obtain a more secure legal position. Applying for a work permit, with its application fee of currently $€ 550$, is a significant investment for migrants in precarious situations. Many interviewed migrants succeeded in obtaining a work permit, although the requirement of a full-time contract complicated the application process. Additionally, work permit applications are subjected to labour market testing, which necessitates that employers have tried to recruit employees through an open call - excluding certain sectors defined as facing labour shortages in national and regional guidelines composed jointly by employment officials, trade unions and employers. As a result, cleaning is the principal sector in which migrants are able to obtain work permits without prior qualifications. The interviewed migrants often preferred restaurant work to cleaning, but immigration regulations interfere in employment, as happened to an asylum seeker from the Middle East who was frustrated by a negative work permit decision: 
Yes, I applied for the work permit, but they didn't accept it. Because they said, 'we give work permits only for cleaning jobs', and my job is in the restaurant field. They say there are enough Finnish people to do restaurant work, so there is no need for foreigners. But there are a lot of open vacancies at the employment office. And my boss said 'we need you at the workplace'. We can take care of ourselves, but they don't give the permit...

Alongside labour market testing, a shortage of permanent work caused problems for regularisation because the issuance of a work permit requires an employment contract guaranteeing full-time working hours. Consequently, a person can be ineligible for a work permit even though their actual working hours are sufficient, as happened to a South Asian asylum seeker whom the author assisted in applying for a work permit in 2016. Having previously rejected a restaurant job because of labour market testing, he was frustrated at not qualifying for a work permit due to having two zero-hour employment contracts, despite working more than forty hours a week in the cleaning sector. Temporary and insecure employment arrangements have a direct effect on regularisation, similar to their effect in regularisation programmes for undocumented migrants that are based on employment provisions (Chauvin et al., 2013). Some interviewed migrants were even ready to pay for a full-time employment contract that would enable them to apply for a work permit, as an interviewed African asylum seeker explained:

I paid this money [€500] for that guy to arrange me the job. He promised to arrange me a permanent job if a pay more, he said I can get a permanent job after six months, if I give more money. I say no problem, because I really needed the work. But I worked just one month there, it was just terrible. 
In the case of labour migrants, the transaction between the employer and the employee involves not only the exchange of wages and labour, but also the right to residence (Rigo 2011: 208). Though employers can act as benevolent guardians of migrant workers, their ability to indirectly sanction the right to residence also restricts migrants' 'exit power' from poor or even intolerable working conditions (cf. Alberti, 2015). The work permit allows a person to change employer in the same sector, but switching to another sector requires a new application and carries with it the risk of a negative decision. The work permit involved a trade-off for the interviewed migrants, in that an improvement in legal status took place at the expense of freedom in the labour market. For example, a South Asian asylum seeker commented after receiving a work permit that 'it was in a way better not to have this permit':

I'm just worried about what kind of continuous permit it is. Does it mean I have to continue in this sector until the end of my life? Because it's not the job I want to do. But sometimes you don't have a choice and you start to do something until the time comes when you get the job you want. But now it sounds somehow compulsory that you have to do this job and you have no choice.

Deportability and limited rights characterise the situation of legal migrants before they obtain a permanent residence permit, which in Finland requires four years of residence with a continuous residence permit. Immigration regulations can continue to frame the employment of migrants who are in a secure legal position, however, due to the income requirements for family reunification. Currently, the required monthly net income for a family of two adults and two children is $€ 2,600$. One African interviewee who worked as a cleaner was desperate at the time of his interview because of the income requirement of more than $€ 3,000$ to get his wife and children to Finland. Family life becomes contingent on wages, which consequently excludes the possibility of family 
reunification for those working in the low-paid sectors. Restrictions on family reunification also indirectly transform the stakes in employment due to of the need to send remittances to dependent family members abroad. As immigration regulations increase the need for income, migrants are required to become 'labour migrants' regardless of their initial entry category.

\section{Juridical division of labour in the low-paid service sector}

Contrary to the official model of labour migration, in which migrant workers are recruited from abroad, employer interviewees reported a surplus of migrant job seekers already in Finland. Consequently, employers had an abundance of applications and did not have to put any effort into recruitment, not to speak of recruitment from aboard, which would require considerable resources. In practice, employers had outsourced recruitment to employed migrant workers, who used their personal networks to find new employees as needed. Due to the lack of Finnish applicants, one interviewed employer concluded, 'I would probably have needed to quit the business without migrant workers'. The interviewed employers had highly positive views of migrants as hardworking, motivated and flexible employees who are rarely absent from work. Another employer in the cleaning sector said that she would prefer not to hire Finnish employees at all, highlighting the difference in attitudes to work:

\footnotetext{
The attitude to work. A Finn can get a job for sure, but we are in the cleaning sector, there are no Finns here anymore, they don't apply for these wages. [...] Those foreigners have in a way that little fear back there, that's the truth, they come here, and they do the work really well and get the wages for that.
}

The interviewed employers were aware of the precarious position of migrant employees who are to varying degrees subject to immigration regulations, even if they did not 
explicate legal status as a factor affecting the recruitment process. Rather than preferring particular ethnic and racial groups over others - what Waldinger and Lichter (2003) call 'hiring queues' - employers are primarily interested in whether workers will accept particular employment conditions (Anderson and Ruhs, 2010). In the context of the Nordic welfare state, access to social benefits significantly changes the bargaining position of workers. For those entitled to unemployment benefits, short-term and flexible employment arrangements offer little incentive to work because of the probable discontinuity and insecurity of income. In contrast, migrants dependent on the income due to their conditional legal status have 'that little fear back there'. The protection of national labour markets through labour market testing can result in safeguarding employment opportunities for local workers who lack interest in the jobs in question, as an interviewed employer in the restaurant sector implied:

Instead of employing a motivated immigrant who is willing to work, willing to learn and integrate through work, [that person] doesn't get a chance, but we are obliged to recruit somebody else, which in the worst case is [an unemployed] person, half-forcibly activated by the employment office, a person with a Finnish background, who couldn't care less about the job.

In interviewed companies, management positions were held by Finnish citizens, while migrant workers mainly executed allocated tasks at various work sites. The multiplication of migrant labour also occurred within companies, as they employed migrants with a variety of legal statuses, such as students, asylum seekers and work permit holders, in addition to Finnish citizens and EU citizens - and even undocumented migrants. Indeed, some employers had been fined for employing migrants who did not have the legal right to work in Finland. While some interviewed employers had provided full-time employment contracts for working migrants, even 
those companies employed a significant number of part-time workers, often with zerohour contracts, because of the variable demand for services. Moreover, migrants in temporary legal positions had a significant role in providing flexibility, in contrast to work permit holders. By institutionalising migrant labour, the work permit system creates obligations for employers to provide full-time work, limiting work permit holders' flexibility compared to other non-recognised categories of migrant workers. While recognising the problem faced by migrants aspiring to obtain a work permit, most interviewed employers were reluctant to provide full-time contracts, as one of them in the cleaning sector explained:

A: We haven't gotten into that. If we applied for that work permit, then we would have a lot of obligations to employ that person, that particular person. Q: Full-time.

A: Full-time and that does not fit for us. This has probably been a problem for foreign workers, that they can't get full-time work everywhere, so they can't fulfil the requirements to renew the visa because they don't have enough money. Q: Are there a lot of requests to apply for a work permit? A: Yes, yes, but I don't want to get into that swamp.

With regards to the aims of immigration policies, a somewhat paradoxical situation has emerged in the Helsinki area: migrants in precarious situations such as asylum seekers and students are more desirable as employees than both local workers and 'labour migrants' (i.e. work permit holders) due to their flexibility and disposability. Even if a migrant employee is deported, the available reserve of migrant workers tempers the disturbance in production caused by immigration policies. Despite the high turnover of labour, dependence on migrant labour is a structural phenomenon in the low-paid service sector: if a migrant employee leaves the job because he or she has found more 
secure employment, received a permanent residence permit or been deported, a new migrant in a precarious position will be available to take his or her place. According to some interviewed migrants, there seemed to be an acknowledged preference for migrants without permanent status, at least among some companies. An African student explained the situation in the labour markets in the following way:

He [the employer] didn't want to work with students, but instead wanted to employ asylum seekers or someone without papers. So that he could exploit the person, because if you are a student, you have a permit and you could sue him. [...] And it's quite funny because you have no choice: either you're in or you're out, if you are not doing the job, someone else is doing it. It's really crazy.

Despite having a residence permit, the interviewee struggled to support himself and fulfil the income requirement for a study permit. The significant role played by migrant labour in the service sector did not translate into secure employment relations because of the limited bargaining power of migrant labour resulting from their dependence on paid employment. Immigration regulations hinder the worker's ability to leave exploitative work, whether because one's right to reside in Finland is at stake either directly, in the case of work permits, or indirectly through income requirements. The multiplication of labour is reflected in the new dynamics of the labour market - in the juridical division of labour - where migrants in temporary legal positions provide labour market flexibility, in contrast to local workers and labour migrants.

\section{Conclusions}

This article focused on the legal significance of employment for migrants who had arrived in Finland as students or asylum seekers and who had worked in mobile and flexible jobs in the low-paid service sector in the Helsinki area. While different 
subjective factors affect migrants' willingness to accept precarious employment arrangements, the analysis presented highlights the role of immigration regulations in informing migrants' employment before obtaining permanent residency. In addition to offering means of support, employment had a strategic role in accumulating the funds to fulfil income requirements for residence permits or in obtaining a more secure status by applying for a work permit. However, labour market testing and the requirement of fulltime employment complicated regularisation for working migrants, including asylum seekers, for whom employment emerged as an alternative path to residency in the prospect of a negative decision and removal. While the interviewed migrants had an instrumental relation to work, it was the immigration system, not their home countries, that established a frame of reference for their employment. Indeed, migrants' employment during the immigration process may become overdetermined by immigration regulations, from finding a job eligible for a work permit to accumulating enough savings to renew a study permit or fulfil the income requirements for family reunification. Therefore, migrants can become 'target earners' (Piore, 1979) with respect to the financial requirements for residence permits.

The concept of the juridical division of labour introduced in this article highlights the relevance of differential legal entitlements between local workers and migrant workers, and among the latter group, of the changing dynamics of supply and demand in the labour market. Migrants in conditional legal positions, such as asylum seekers and students, constitute a non-recognised labour supply, which service sector employers prefer in recruitment over local workers and work permit holders due to their flexibility. Immigration regulations produce differentiated forms of labour through various restrictions on residence time, welfare benefits and labour market mobility among different entry categories, even if juridical hierarchies do not translate 
straightforwardly to the labour market. While Finnish workers, EU citizens and permanent immigrants are also employed in the service sector, other studies (Ollus, 2016; Maury, 2017) completed in Finland demonstrate that flexible employment arrangements are typical for non-EU migrants in precarious legal positions. The lack of statistics on migrants' labour market participation by entry category complicates the assessment of the overall situation. Therefore, the extent of the juridical division of labour remains subject to further empirical research, which would include EU citizens and other migrant groups in the analysis. Nevertheless, facilitating migrants' access to welfare services and the flexibilisation of work permit policies - including a transition from monthly to annual income requirements and removal of sectoral restrictions would improve the position of migrants already working in the country, rather than leading to a significant increase in the recruitment of migrant workers from abroad. The overrepresentation of migrant workers in low-paid labour markets in Western countries is usually interpreted as a racial or ethnic division of labour, or as a division between 'local workers' and 'migrant workers' (e.g. Wills et al., 2010). The concept of the juridical division of labour highlights the discriminating and differentiating effects of immigration policies on migrants' position in the labour market before obtaining permanent status. In fact, due to the proliferation of legal statues, there are no 'migrant workers' as such: migrants who work are in a variety of different legal positions, including various forms of sector-specific and skilled labour migrants, irregular migrants and migrants with a humanitarian-, study- or family-based status, representing different intersections between immigration regulations, labour markets and the welfare state. While irregular migrants working in precarious conditions are considered a paradigmatic example of the negative effects of precarious legal status on labour market position, immigration regulations also exacerbate legal migrants' 
vulnerability in the labour market through requirements of economic self-sufficiency and by restricting social rights. As increasing numbers of migrants work for years in legally disadvantaged positions in the labour market, it is necessary that the discussion on migrant labour consider the structural effects of immigration policies in order to avoid the ethnicisation of labour market changes.

The function of employment as a precondition for residence and rights points to a new kind of neoliberal selective logic in immigration policies, by which economic contributions become decisive criteria for qualification. This shift from normative to economic assessment of deservingness is also evident in the case of humanitarian migrants due to the income requirements for family reunification; employment, if it leads to a work permit, can even become a substitute for international protection. As immigration regulations increase migrants' dependency on paid employment, migrants are required to become 'labour migrants' regardless of their initial entry category. Instead of a threat to labour standards, migrants' precarious position in the labour market can be regarded as mirroring wider social transformations, or as a laboratory for neoliberal policies that can affect the entire population. Due to their conditional legal position, migrants are well-integrated into the world of precarious work: they are ideal neoliberal subjects, ready to take any job available.

\section{Acknowledgements}

I would like to thank the editor, my anonymous reviewers, the fellows of the Institute for Advanced Social Research at the Tampere University and Niina Vuolajärvi for their valuable comments on earlier versions of this article.

\footnotetext{
${ }^{1}$ In the most cases, however, tuition fees are defrayed in whole or in part by scholarship
} schemes. 
${ }^{2}$ The interviewed migrants were from Afghanistan, Cameroon, China, Congo, Ethiopia, Iran, Iraq, Kenya, Morocco, Nigeria, Sri Lanka, Turkey and Zimbabwe.

${ }^{3}$ The number of employer interviews remained low because many of the companies contacted for an interview declined to participate. 


\section{References}

Abbasian S and Hellgren C (2012) Working Conditions for Female and Immigrant Cleaners in Stockholm County: An Intersectional Approach. Nordic Journal of Working Life Studies 2(3): 161-181.

Aguiar L and Herod A (eds) (2006) The Dirty Work of Neoliberalism: Cleaners in the Global Economy. Malden: Wiley-Blackwell.

Ahmad AN (2008) Dead men working: Time and space in London's ('illegal') migrant economy. Work, Employment and Society 22(2): 301-318.

Alberti G (2014) Mobility strategies, 'mobility differentials' and 'transnational exit': The experiences of precarious migrants in London's hospitality jobs. Work, Employment and Society 28(6): 865-881.

Anderson B (2010) Migration, immigration controls and the fashioning of precarious workers. Work, Employment and Society 24(2): 300-317.

Anderson B and Ruhs M (2010) Migrant workers: Who needs them? A framework for the analysis of staff shortages, immigration and public policy. In: Ruhs M, Anderson B (eds) Who Needs Migrant Workers? Oxford: Oxford University Press, 15-52.

Berntsen L (2016) Reworking labour practices: On the agency of unorganized mobile migrant construction workers. Work, Employment and Society 30(3): 472-488.

Boltanski L and Chiapello E (2005) The New Spirit of Capitalism. London: Verso.

Bosniak L (2006) The Citizen and the Alien. Princeton: Princeton University Press.

Calavita K (2005) Immigrants at the Margins: Law, Race, and Exclusion in Southern Europe. Cambridge: Cambridge University Press.

Castles S (2011) Migration, Crisis and the Global Labour Market. Globalizations 8(3): $311-324$. 
Chauvin S, Garcés-Mascareňas B and Kraler A (2013) Working for Legality:

Employment and Migrant Regularization in Europe. International Migration 51(6): 118-131.

Coutin SB (2003) Legalizing Moves: Salvadoran Immigrants' Struggle for U.S.

Residency. Ann Arbor: University of Michigan Press.

Dauvergne C and Marsden S (2014) The Ideology of Temporary Labour Migration in the Post-Global Era. Citizenship Studies 18(2): 224-242.

De Genova N (2002) Migrant 'Illegality' and Deportability in Everyday Life. Annual Review of Anthropology 31: 419-447.

Esping-Andersen G (1990) The Three Worlds of Welfare Capitalism. Princeton:

Princeton University Press.

Foucault M (2008) The Birth of Biopolitics: Lectures at the Collège de France 19781979. Basingstoke: Palgrave.

Freedland M and Costello C (2015) Migrants at Work and the Division of Labour Law. In: Costello C, Freedland M (eds) Migrants at Work: Immigration and Vulnerability in Labour Law. Oxford: Oxford University Press, 1-26.

Friberg J and Midtbøen A (2018) Ethnicity as skill: Immigrant employment hierarchies in Norwegian low-wage labour markets. Journal of Ethnic and Migration Studies 44(9): 1463-1478.

Goldring L and Landolt P (2011) Caught in the Work-Citizenship Matrix: The Lasting Effects of Precarious Legal Status on Work for Toronto Immigrants. Globalizations 8(3): 325-341.

Goldring L and Landolt P (2013) Precarious Legal Status in Canada: Theorizing Noncitizenship and Conditionality. In: Goldring L, Landolt P (eds) Producing and 
Negotiating Non-Citizenship: Precarious Legal Status in Canada. Toronto:

University of Toronto Press, 3-27.

Immigration Office (2017) Maahanmuuton tunnusluvut [Key Figures in Immigration].

Available at: http://emn.fi/files/1528/Tilastokatsaus_2016_FI_netti.pdf

(consulted 12 November 2017).

Karakayali S and Rigo E (2010) Mapping the European Space of Circulation. In: De

Genova N, Peutz N (eds) Deportation Regime. Sovereignty, Space, and the

Freedom of Movement. Durham: Duke University Press, 123-144.

Könönen J (2018) Differential Inclusion of Non-Citizens in a Universalistic Welfare

State. Citizenship Studies 22(1): 53-69.

Lewis H, Dwyer P, Hodkinson S and Waite L (2014) Hyper-precarious lives: Migrants, work and forced labour in the Global North. Progress in Human Geography 39(5): 580-600.

Maury O (2017) Student-Migrant-Workers: Temporal aspects of precarious work and life in Finland. Nordic Journal of Migration Research 7(4): 224-232.

McCollum D and Findlay A (2015) 'Flexible' workers for 'flexible' jobs? The labour market function of A8 migrant labour in the UK. Work, Employment and Society 29(3): 427-443.

McDowell L, Batnitzky A and Dyer S (2009) Precarious Work and Economic Migration: Emerging Immigrant Divisions of Labour in Greater London's Service Sector. International Journal of Urban and Regional Research 33(1): $3-$ 25.

Mezzadra S and Neilson B (2013) Border as Method; or, The Multiplication of Labor. Durham: Duke University Press. 
Moulier Boutang Y (2002) Dalla Schiavitù al Lavoro Salariato [From Slavery to Wage Labour]. Rome: Manifestolibri.

Ollus N (2016) Forced Flexibility and Exploitation: Experiences of Migrant Workers in the Cleaning Industry. Nordic Journal of Working Life Studies 6(1): 25-45.

Pastore F (2014) The Governance of Migrant Labour Supply in Europe, Before and During the Crisis. Comparative Migration Studies 2(4): 385-415.

Piore MJ (1979) Birds of Passage. Migrant Labor and Industrial Societies. Cambridge: Cambridge University Press.

Rigo E (2011) Citizens despite Borders: Challenges to the Territorial Order of Europe. In: Squire V (ed) The Contested Politics of Mobility: Borderzones and Irregularity. Abingdon: Routledge, 199-215.

Robertson S (2011) Student switchers and the regulation of residency: The interface of the individual and Australia's immigration regime. Population, Space and Place 17(1): 103-115.

Rosewarne S (2010) Globalisation and the Commodification of Labour: Temporary Labour Migration. The Economic and Labour Relations Review 20(2): 99-110. Ruhs M and Anderson B (2010) Semi-compliance and illegality in migrant labour markets: An analysis of migrants, employers and the state in the UK. Population, Space and Place 16(3): 195-211.

Sassen S (2001) The Global City: New York, London, Tokyo. Princeton: Princeton University Press.

Schuster L (2005) The Continuing Mobility of Migrants in Italy: Shifting between Places and Statuses. Journal of Ethnic and Migration Studies 31(4): 757-774.

Sharma N (2006) Home Economics: Nationalism and the Making of 'Migrant Workers' in Canada. Toronto: University of Toronto Press. 
Skeggs B (2004) Class, Self, Culture. Abingdon: Routledge.

Standing G (2011) The Precariat: The New Dangerous Class. London: Bloomsbury Academic.

Waldinger R and Lichter M (2003) How the Other Half Works: Immigration and the Social Organization of Labor. Berkeley: University of California Press.

Wills J, Datta K, Evans Y, Herbert J, May J and McIlwaine C (2010) Global Cities at Work: New Migrant Division of Labour. London: Pluto Press.

Jukka Könönen is Postdoctoral Research Fellow in the Institute for Advanced Social Research at Tampere University. His research interests include criminalisation of migration, European border regime, immigration law, labour market transformations and precarisation of labour. Recently, he has conducted research on immigration detention and deportation system in Finland. 